\title{
Family Businesses in Eastern European Countries: How Informal Payments Affect Exports
}

\author{
Thomas Bassetti* \\ Lorenzo Dal Maso ${ }^{\dagger}$ \\ University of Padua \\ University of Florence \\ Nicola Lattanzi $i^{\ddagger}$ \\ University of Pisa
}

\begin{abstract}
This paper explores the relationship between the cost of corruption and market orientation of family firms in Eastern European countries. Using the Business Environment and Enterprise Performance Survey and panel data methods, we obtained several results. First, in contrast to nonfamily firms, family firms are particularly sensitive to corruption. Second, informal payments aiming to facilitate business operations tend to support export-oriented firms. Finally, family firms that sell their product mostly in the domestic market tend to bribe public officials to secure government contracts. This study has important implications in terms of market efficiency. Policies devoted to remove those inefficiencies that hamper business operations would mainly increase the competitiveness of family firms.
\end{abstract}

JEL codes: O12, O17, P2.

Keywords: Informal payments, family business, company export orientation, Eastern European economies.

\footnotetext{
*Corresponding author. Department of Economics and Management "Marco Fanno", University of Padua, Via del Santo 33, 35123 Padova, Italy. Email: thomas.bassetti@unipd.it., Phone: +390498274003 .

${ }^{\dagger}$ University of Florence, Department of Business and Economics, Via delle Pandette, 9, 50127 Florence, Italy. E-mail: lorenzo.dalmaso@unifi.it. Phone: +390554374684.

${ }^{\ddagger}$ University of Pisa, Department of Economics and Management, Via Cosimo Ridolfi, 10, 56124 Pisa, Italy. E-mail: lattanzi@ec.unipi.it. Phone: +390502216342.
} 


\section{Overview and detailed aspects}

Can Eastern European economies develop strong family business sectors? In some countries there is an embedded desire to pass the business on down the generations, while there are countries such as Russia where successful entrepreneurs do not tend to have dynastic intentions. Ionov (2014) identifies different reasons why this happens. According to the author, corruption, real and perceived, represents a deterrent to the development of family businesses. This seems to be in collusion with previous results. As stated by Bertrand \& Schoar (2006:92): 'some papers such as Burkart, Panunzi \& Shleifer (2003) and Caselli \& Gennaioli (2003) begin with an argument that if formal institutions regarding investor protection, contract enforcement or property rights protection are weak or nonexistent, strong family ties may provide a second-best solution for the development of economic activity'.

This paper investigates whether family firms operating in Eastern European countries are affected by corruption and also the existing link between the export share of family firms and informal payments. We focus on the level of export, since we consider it as an important, as well an invaluable, method to support and enhance firms' growth.

The persisting financial difficulties of the Euro area, the weak recovery in several other advanced economies (e.g. United States), the expected slowdown in economic growth in China and India as a result of a continuous increasing in the volatility of financial markets, leads institutions to ask which regions can drive growth and employment creation in the short to medium term (Schwab, 2012). Nowadays, according to Schwab (2013:xiii), 'policymakers must avoid complacency and press ahead with the structural reforms and critical investments required to ensure that their countries can provide a prosperous environment and employment for their citizens. They must identify and strengthen the transformative forces that will drive future economic growth'. In this perspective, future economic growth can be also reached by setting most of the policymakers' reforms around the family business. This is because family firms are the prevalent form of business worldwide and because they play a significant role in the global economy (Prencipe et al., 2014).

Nevertheless, when we talk about family firms there is a common perception that family-owned businesses do not grow. Citing Ward (1997:323), we can say that 'businesses fail because, more often than not, these people never make the decisions needed to ensure the vitality of their companies in an everchanging, even more complex world'. Ward continues with the adage 'from shirtsleeves to shirtsleeves in three generations' by which he expresses the widespread perception that family firms do not survive over the long term. Most of the family-business owners rank the six most powerful challenges to the long-term growth of their respective firms in the following order: (1) maturing business life cycles and increasing competition, (2) limited capital to fund both family needs and business growth needs, (3) weak next-generation business leadership, (4) entrepreneurial leadership's inflexibility and resistance to change, (5) conflicts among sibling successors and (6) disparate family goals, values, and needs (Ward, 1997:325). Generally, these are the most frequent reasons why family firms do not experience growth, but, more importantly why they do not become international firms. The internationalization of family firms has become a doubled-edge sword since, on the one hand, it can enhance a firm's growth while, 
on the other hand, it can destroy family wealth (McConaughy et al., 2001). This is why family firms have traditionally operated in domestic markets.

Notwithstanding, to the best of our knowledge, this study is the first attempt to investigate the role of corruption on the degree of internationalization of family firms operating in Eastern European countries.

The term 'corruption' has been defined in many different ways, which unfortunately differ from each other in some aspects; 'while it may be difficult to describe, corruption is generally not difficult to recognize when observed. In most cases, different observers would agree on whether a particular behavior connotes corruption. Unfortunately, the behavior is often difficult to observe because acts of corruption do not typically take place in broad daylight (Tanzi, 1998:564)'.

Nevertheless, even if it is not easy to define the term corruption there is one definition that has the virtue of simplicity which defines it as 'the act by which insiders profit at the expense of outsiders (Evans, 1999)' or commonly, the abuse of public power for private gain (e.g., Lapalombara, 1994; Habib \& Zurawicki, 2002; Aguilera \& Vadera, 2008; Alon \& Hageman, 2013). This does not mean that corruption exists only within public sector, because it is also a practice well embedded into the private business.

According to Evans, we can group corruption into three main categories, which are: (a) incidental corruption, (b) systematic corruption and (c) systemic corruption. In the first typology, we can find small-scale situations where the actors are represented by junior public officials. This group has the smallest macro-economic cost, nevertheless, it is the most embedded in society and hence the must hard to remove. The second group includes the systematic corruption covering the situation in which the actors are whole-of-government departments or parastatal. This second form of corruption is bigger than the incidental one even if it can include a similar form of government officer since it substantially affects government revenues. Therefore, it can be defeated only through sustained reforms. Finally, there is the systemic corruption, that is, kleptocracy or government by theft. According to Evans (1999:7), in this situation honesty becomes irrational, and there is a huge developmental impact.

From the previous literature, we know that corruption is one of the most significant impediments to economic growth. It has a negative direct impact over all aspects of a nation's economic development (Campos et al., 1999; Hall \& Jones, 1999; Shleifer \& Vishny, 1993; Mauro, 1995; Robertson \& Watson, 2004; Ampratwum, 2008; de la Croix \& Delavallade, 2009). In particular, it: (a) reduces human capital, (b) discourages investment, (c) leads to a misallocation of resources and (d) lowers the quality of public infrastructure and services. As a result, it is a substantial obstacle to economic development. Notwithstanding, it is noteworthy that no previous studies investigated the link between corruption and firm's export level (especially family firms). This is an interesting topic since export and, more generally, internationalization strategies can be considered as a key determinant of economic growth (see Olney, 2014).

Our analysis is based on firms located in Eastern European countries because they represent a good investigation environment since, as affirmed by the previous literature, transition economies are characterized by a high level of corruption (Hellman et al., 2000; Radaev, 2004; Rose, 2000; Tonoyan et al., 2010). We use the Business Environment and Enterprise Performance Survey (BEEPS). This is a repeated survey that allows us to consider firm-level data 
on a broad range of dimensions. In particular, starting from two initial waves, 2002 and 2005, we construct a panel data set distinguishing between family and non-family firms. As dependent variable, we use the percentage of sales exported in the last fiscal year while the main explanatory variable is constituted by an interaction term between the percentage of total annual sales paid in informal payments and a dummy variable indicating whether the firm is a family business or not. For the purpose of our research, we define a family business following Shanker \& Astrachan (1996) and Litz (1995). According to these authors, a business can be defined as a family firm when the family has some degree of control over strategic decisions. ${ }^{1}$ Obviously, it is always difficult to identify family business phenomena. However, we adopt some confounding reasonings to distinguish between family and individual business effects.

After having tested for the opportunity of a fixed effects approach, we estimate three different models: a traditional linear model with the inclusion of a firm's specific effects, a stepwise regression model to address multicollinearity problems and a semiparametric model to account for the fact that the majority of firms do not export. We obtained several results. First, in contrast to non-family firms, family firms are particularly sensitive to corruption. Second, informal payments aiming to facilitate business operations tend to support export-oriented firms. Finally, family firms that sell their product mostly in the domestic market tend to bribe public officials to secure government contracts. This study has important implications in terms of market efficiency. Policies devoted to remove those inefficiencies that hamper business operations would mainly increase the competitiveness of family firms.

With respect to the existing literature, our study represents the first attempt to explore the relationship between corruption and family firms' level of export. Most of the literature has studied how firms' characteristics influence export decisions and international strategies. However, policymakers are not able to intervene directly on these characteristics whereas our study may provide useful insights to increase market efficiency.

The rest of the paper is organized as follows. Section 2 reviews the economic literature on the link between family firms and internationalization strategies; Section 3 describes the data set. Section 4 illustrates the econometric methods we use, while Section 5 presents our main findings. Finally, Section 6 concludes the discussion by providing some important policy implications.

\section{Internationalization of family firms}

Family firms, defined as businesses 'governed and/or managed with the intention to shape and pursue the vision of the business held by a dominant coalition controlled by members of the same family or a small number of families in a manner that is potentially sustainable across generations of the family or families' (Chua et al., 1999:25), play a crucial role across all economies in the world.

\footnotetext{
${ }^{1}$ The BEEPS relies on a self-identification method asking respondents the following question: "Which of the following best describes the largest shareholder(s) in your firm?". The possible answers were: individual, family, domestic company, foreign company, bank, investment fund, managers of the firm, employees of the firm, government or government agency, others and don't know. Notice that possible respondents were: chief executive, president, vice president, director, finance officer, general manager, managers or owner.
} 
The role that such firms play in worldwide economies (Beckhard \& Dyer, 1983; Stern, 1986; Aronoff \& Ward, 1995; Neubauer \& Lank, 1998; La Porta et al., 1999; IFERA, 2003) is well recognized. Prencipe et al. (2014) provide interesting data: according to the Family Firm Institute (2008), family firms are estimated to produce the $70-90 \%$ of global GDP annually. With respect to different geographical context, in North America, family-owned businesses are about eighty to ninety per cent of all enterprises contributing $64 \%$ of the GDP and employing $62 \%$ of the US workforce. With respect to the European market, we can find similar results: France has $83 \%$ of businesses classified as family firms, in Germany $79 \%$ of those firms employ about $45 \%$ of the country's workforce and contribute to the $40 \%$ of the national turnover, while in Italy family-owned firms constitute $73 \%$ of businesses that employ over $50 \%$ of the Italian workforce. Therefore, it is easy to understand why such firms play an important role in today's global economy (Zahra, 2003).

However, even if the worldwide role of family firms is well acknowledged, there is still an issue that has to be managed with respect to the possible classification of those firms. Nowadays, there is no unique definition of a family business because 'Researchers continue to disagree over the definition of a family business [...] and there has not yet appeared a framework to help integrate the many promising approaches (e.g., from strategic management, organizational theory, economics, sociology, anthropology and psychology) used by researchers to study family firms $(. .$.$) . The theoretical issues with respect to$ defining the family firm are still open to debate' (Chrisman et al., 2005). This leads to difficulties in comparability between studies and, most important, results. In this respect, a study conducted on behalf of the European Commission (KMU Forschung Austria, 2008) mapped the definition of 'family business' in 33 countries, looking at policy discussions, legal regulations as well as academic research; the result was a list of 90 different definitions of family business. This abundance of definitions and measurements of family firms signals the difficulty in reaching a common operational definition (Prencipe et al., 2014:7).

Notwithstanding, researchers use three different approaches to analyze family firms: (a) traditional, (b) sociological and (c) general management. Through the traditional view, researchers consider the dimension of the company as the discriminant between family and non-family firms. Indeed, this approach considers only those family firms of small size, characterized by a slow growth process and a patriarchal style of leadership applied on a flat structure (Casson, 2000).

The second approach is the sociological one (Beckhard \& Dyer, 1983; Davis, 1983; Lansberg, 1983; Kepner, 1991). Thanks to this perspective, the family is considered as an institution that issues the firm's strategies and the related politics. The sociological view focuses on the relationships generated by the involvement of the family in the business (the family and the firm) (Lansberg, 1983).

Finally, the managerial approach includes: (a) the mono-variables and (b) the multi-variable groups. The former considers the ownership as the only relevant variable to describe the family firm character. The latter, which is more complex, considers other sensitive dimensions such as the generational transition process, the level of involvement of each family member in the business, their role in the firm's governance and administration and finally the dimension related to the culture (Lattanzi \& Lazzini, 2005). 
Handler (1989) used a multi-variables approach which considers: (a) the generational transition process, (b) the firm's management and (c) the ownership as the fundamental dimensions included into the family business. Similar approaches were adopted by other important scholars who focused their studies on the family's capacity to set the strategies of a firm (Donnelley, 1964; Davis \& Tagiuri, 1989; Shanker \& Astrachan, 1996). An important contribution is given by Habbershon et al. (2003), which extends the implication of the resource-based view theory to the family business. They define the "familiness" as unique, inseparable, and synergistic resources and capabilities that arise from family involvement in the firm and interactions. Chrisman et al. (2005) build a systematic approach in which they consider that possessing the resources, the intention, and the vision without the proper behavior does not make a firm a real family firm. As a result, the essence of a family firm requires: (a) the intention to maintain family control of the dominant coalition; (b) unique, inseparable, and synergistic resources and capabilities arising from family involvement and interactions; (c) a vision set by the family dominant coalition and intended for trans-generational pursuance and $(\mathrm{d})$ the pursuance of such a vision (Chrisman et al., 2004; Habbershon et al., 2003).

Thanks to this definition, we are now able to understand which is the most important contribution given by the presence of family within the business. Family vision imposes that family firms set their strategies according to a longterm vision. This is mainly because personal goals, rather than the financial and profitability goals, are grounded on business continuity and emotional behaviors such as placing more emphasis on research and development, building reputation, and improving or broadening market share (Miller \& Le Breton-Miller, $2005)$

This behavior is explained in the academic debate through the socioemotional wealth (SEW) theory. According to this theory, the decisions of principals in family firms are motivated by the desire to preserve accumulated socioemotional endowment even when it contrasts with typical economic and/or financial goals (Prencipe et al., 2014:6).

The SEW framework has received extensive empirical support from a number of studies because when family firms aim to preserve family socioemotional wealth 'they give up the opportunity to join a lucrative co-operative, they invest less in research and development (R\&D), and they diversify less (Chrisman \& Patel, 2012; Gómez-Mejía, Cruz, Berrone, \& Castro, 2011; Gómez-Mejía et al., 2007, 2010, in Chen et al., 2014:134)'. Therefore, what the SEW theory assesses is that generally family firms tend to limit firm's future opportunities to growth when it can damage the stock of socioemotional wealth. This is more visible when we talk about firms' internationalization.

Globalization has forced and is currently still forcing firms of all sizes and ownership types to expand their business broadly (Parker, 1998; Zahra \& George, 2002; Zahra, 2003). The export market is recognized to be an important, as well an invaluable, method to boost firms' growth and to increase market share when domestic market is full.

As a result family firms, which traditionally have operated in domestic markets, are forced to get an international profile in order to survive. In doing so, as aforementioned, internationalization becomes a doubled-edge sword for a family business: it allows the risk to be spread across geographic segments but also carries a higher risk of losing wealth (McConaughy et al., 2001; Merino et 
al., 2012). Hence, the SEW theory explains why internationalization (with a specific concern for export) can be limited in family firms.

Previous literature highlights that firms' internationalization is influenced by two factors: (a) the external environment and (b) firms' specific factors. Point (a) impacts indirectly through the high level of domestic competition together with the high level of technological change forced by the internationalization process (Ward, 1997). On the contrary, point (b) refers to two different specific factors: tangible and intangible values. These can be considered as the sum of knowledge, culture, ownership and governance (Dunning, 1988; Lu \& Beamish, 2001; Sanders \& Carpenter, 1998; Zahra, 1996; Corbetta \& Montemerlo, 1999; Zahra, 2003). Kontinen \& Ojala (2010) present a framework in which limited financial capital possibility of long-term planning, making quick decisions and fear of losing control are the main factors affecting family firms' internationalization.

In particular, ownership influences mostly the level of internationalization: 'Ownership aligns the interests of the family firm and its managers (Lansberg, 1999; Sharma et al., 1996) and promotes executives' willingness to purse risky activities such as international expansion (Gallo \& Pont, 1996) [...] Internationalization is a risky strategic move that can trigger conflicts within the family firm. Owner-managers might want to internationalize their operations to satisfy their own needs for achievement at the expense of the wealth of their family. Internationalization may take years to generate profits, depriving the family of short-term wealth. It also requires different types of capabilities from those that already exist within the firm (Zahra \& Garvis, 2000). Resolving these issues requires in addressing the conflicts that arise over concerns that internationalization may alter the firm's labor force, values and organizational culture' (in Zahra, 2003: 498). There are studies that highlight a positive relationship between family ownership and internationalization process (Zahra, 2003) while, Fernandez \& Nieto (2006) found the opposite result, that is, a negative correlation between internationalization level and family ownership.

A recent research (Sciascia et al., 2012) suggests that the family ownership has a curvilinear effect on the internationalization of family businesses. A moderate level of ownership is associated with a high level of internationalization, while low and high levels of ownership are associated with low levels of internationalization (Astrachan, 2010). This phenomenon can be explained through two complementary perspectives: (a) the stewardship theory (Davis et al., 1997) and (b) the stagnation theory (Miller et al., 2008). According to the former, an owner considers its firm as an asset that has to be passed down through generations rather than as an amount of wealth to consume (see Casson, 1999). Therefore, the internationalization process is relevant to the firm's long-term survival even if it is correlated with a higher economic risk. In contrast, the stagnation theory assesses that resource restrictions, conservative strategies and family conflicts are considered as the most relevant reasons why family businesses find difficulties of growth (see Landes, 1949 ; Levinson, 1971; Chandler, 1990; Poza et al., 1997; Jehn, 1997; Grassby, 2000; Allio, 2004; Schulze et al., 2003; Sciascia et al., 2012). 


\section{Data}

To study how informal payments affect family firms' export share, we construct a panel data set using the BEEPS, a repeated survey developed jointly by the European Bank for Reconstruction and Development and the World Bank. This data set allows us to consider firm-level data on a broad range of dimensions: business environment, performance of firms, business-government relations, firm financing, labor, infrastructure, informal payments and corruption, and other topics such as training and innovation. The BEEPS was initially conceived to build comparative measures across transition economies. For this reason, first rounds only considered Eastern European countries, the former Soviet Union and Turkey. In contrast, more recent surveys include a larger number of countries. However, these waves do not distinguish between family and non-family businesses. Therefore, in order to conduct our analysis, we relied on two initial waves, 2002 and 2005, respectively. Both waves were designed to be as representative as possible of the population of firms within the industry and sector. To ensure a sufficient number of observations in the tails of the distribution of firms, initial rounds were based on a random sampling technique supplemented by elements of quota restrictions. The sampling strategy is particularly relevant in panel data studies because fixed effects estimates can be generalized to the entire population only if firms have similar values of independent variables. Table 1 describes our variables and provides some summary statistics.

As dependent variable, we consider the percentage of sales exported by the establishment. This percentage includes both direct and indirect exports (i.e., exports that are mediated by a third party). The average export share is $10.19 \%$, while domestic markets cover something like $89.81 \%$ of total sales. As expected, internationally-oriented firms represent a small fraction of the population. This means that our dependent variable is left-censored. More specifically, by looking at the distribution of the dependent variable, the $74.71 \%$ of firms do not sell their products abroad; on the contrary, only a $1.76 \%$ of firms export all their production.

Since firms may decide to export in order to avoid significant informal costs, we use two alternative measures of informal payments. A first measure concerns the fraction of sales paid in order to bribe public officials. In this case, respondents were asked: "It is said that establishments are sometimes required to make gifts or informal payments to public officials to 'get things done' with regard to customs, taxes, licenses, regulations, services, etc. On average, what percent of total annual sales, or estimated total annual value, do establishments like this one pay in informal payments or gifts to public officials for this purpose?". The second measure refers to the fraction of contract value that an establishment pays to secure or attempt to secure a government contract. In particular, respondents were asked: "When establishments like this one do business with the government, what percent of the contract value would be typically paid in informal payments or gifts to secure the contract?". In order to investigate how informal costs influence the family firm's decision to export, we interact these two measures of corruption with a dummy variable taking value one if the establishment belongs to a family business and zero otherwise.

Obviously, in this context, causality problems may arise. For instance, informal payments might be requested in order to facilitate the acquisition of particular licenses. Analogously, taxes to export and shipping procedures may 
lead to additional corruption costs. In other words, internationally oriented firms might be subject to additional informal costs. For this reason, we use a control function approach to address endogeneity issues. Following Fisman \& Svensson (2007), we instrument the corruption cost with the average corruption cost reported by other firms within the same country-industry-year. In other words, for each country-industry-year, we compute the average level of informal payments reported by all firms except the firm for which the instrument is computed.

The remaining independent variables include several dimensions that can be potentially related to the export share. We use the establishment's total annual sales, the number of full-time production workers at the end of the fiscal year and the number of full-time temporary employees employed at the end of the last fiscal year in order to control for possible scale effects. Total sales are converted into US Dollars and the average amount of sales is US $\$ 3,385,552$. The average number of full-time permanent production workers is 74.86 , with the largest firm employing 2,535 workers. This number must be augmented by the presence of temporary workers. On average, each firm employs 31.2 full-time temporary workers. Furthermore, we consider the number of non-production workers such as managers, administrators and commercial employees to control for the stimulus to internationalization coming from white collar workers.

Since the capacity to comply with consumers' tastes is crucial to survive in the market, we consider whether $\mathrm{R} \& \mathrm{D}$ activity is stimulated by competitors or consumers. For our firms, customers and domestic competitors are the main sources of innovation. We also control for human capital accumulation exploiting information on investments in formal training programs.

We also use data on access to credit, asset composition and structure of ownership to control for the possible link between physical capital availability and the decision to export. In contrast, the decision to export forces firms to bear additional costs. However, firms facing some liquidity constraints are more vulnerable to international competition. Table 1 shows that our sample is composed of firms that consider access to credit a minor obstacle for their business. At the same time, internal funds represent the $70 \%$ of total capital, with an average share of capital for the largest owner equal to $77.3 \%$.

Finally, we consider the establishment's age and the presence of an internationallyrecognized quality certification. The majority of firms do not own any international certificate. 


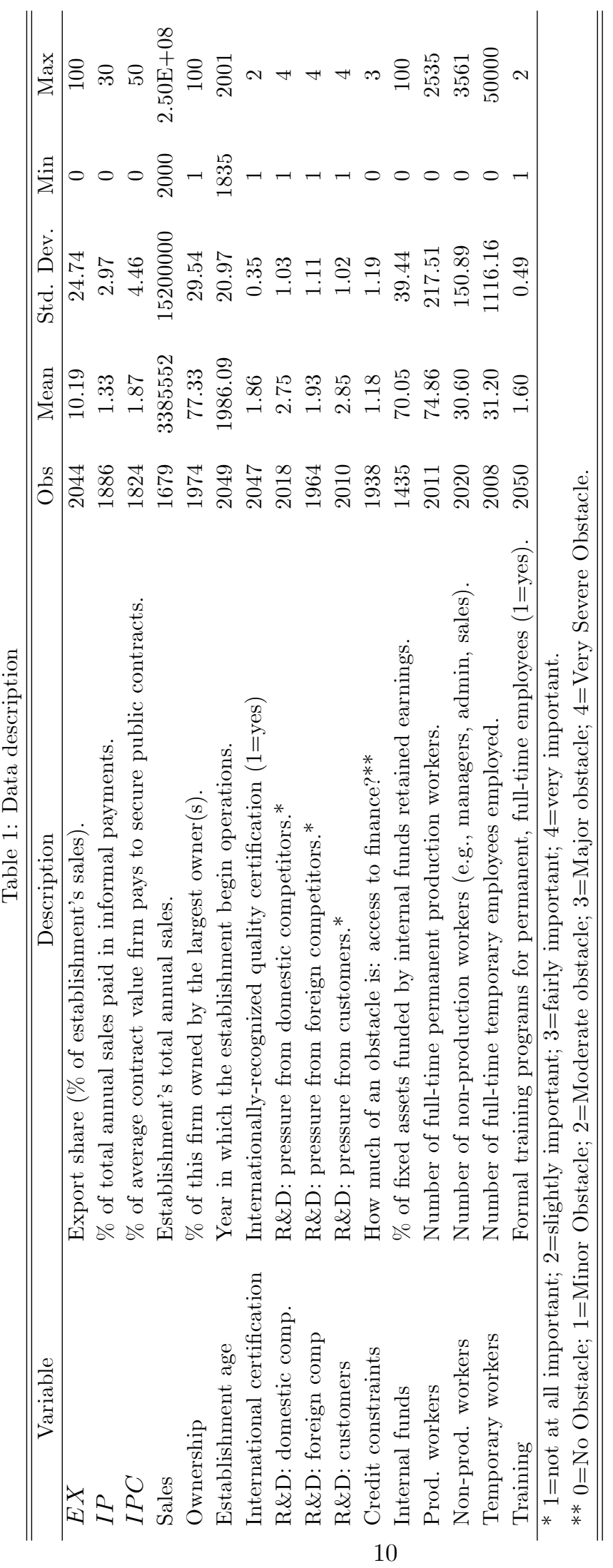




\section{Methodology}

Our analysis aims to establish a link between bribery and the export share. In particular, we want to investigate whether corruption costs influence family firms' export. Given the structure of our data, we must take into account several important issues. First, since firms are heterogeneous, we must consider the effects of this heterogeneity on the decision to export. Second, because many firms simply do not export, our dependent variable is left-censored at zero. Third, delicate questions such as those regarding informal payments may show a high rate of misreporting. In other words, respondents may lie by declaring the absence of informal payments just because they want to hide illegal activities or they want to comply with socially desirable outcomes. Finally, the decision to export may expose firms to additional informal costs. In this case, reverse causality becomes a source of endogeneity bias. Therefore, we proceed by steps, where in each step we address a specific issue.

By exploiting the panel structure of our dataset, we first estimate a linear model with fixed effects. ${ }^{2}$ This method generates estimates that are robust to unobserved, fixed heterogeneity across firms. In particular, we estimate the following specification:

$$
E X_{i t}=\alpha+\beta I P_{i t}+\gamma d_{i} I P_{i t}+\delta^{\prime} X_{i t}+\mu_{i}+\mu_{t}+\varepsilon_{i t},
$$

where $E X_{i t}$ is the export share of firm $i$ at time $t, I P_{i t}$ represents the percentage of sales paid in informal payments by firm $i$ at time $t, d_{i}$ is a dummy variable taking value 1 if firm $i$ is a family business, $X_{i t}$ is a matrix of time-varying covariates, $\mu_{i}$ is the firm-specific effect; $\mu_{t}$ are time dummies and $\varepsilon_{i t}$ is the error term. The usual assumption is that errors are independently and identically distributed. Since we may expect cross-country heteroskedasticity, we use a robust variance matrix to account for correlation within countries (clusters).

Here, the variable of interest is the interaction term $d_{i} I P_{i t}$. This term captures the informal payments declared by family firms; while its coefficient, $\gamma$, represents the correction to $\beta$ necessary to estimate the marginal impact of these costs on export for family businesses. ${ }^{3}$ Note that the direct impact of being a family business is absorbed by $\mu_{i}$.

As mentioned above, survey data on illegal activities may present a systematic error due to different misreporting incentives. This means that, if different categories of respondents have different incentives to misreport the amount of informal payments, our estimates could be biased. We know that the larger the measurement error, the closer are estimators to zero. This underestimation is known as attenuation bias (see Wooldrige, 2002). However, if the measurement error is a fixed effect itself, our estimates completely eliminate the bias.

Since our baseline specification includes several control variables, they are likely to be correlated. This means that our conclusions could be invalidated by the presence of multicollinearity. A common and easy way to select a subset of independent variables from a complex specification is through stepwise regression. This is a semi-automated process of building a model by successively

\footnotetext{
${ }^{2}$ The decision to estimate a fixed effects model is supported by a Hausman specification test (Hausman, 1978).

${ }^{3}$ In model (1), the contribution of corruption can be rewritten as follows: $\left(\beta+\gamma d_{i}\right) I P_{i t}$, where $\beta$ is the marginal coefficient of corruption when $d_{i}=0$, while $\beta+\gamma$ is the marginal coefficient of bribe when $d_{i}=1$.
} 
removing and adding covariates. The subset of explanatory variables is selected on the basis of the t-statistics. That is, a variable enters the final model only if its statistical significance is above a fixed threshold. Although a stepwise regression may be useful in addressing multicollinearity problems, an improper use of this technique may lead to a poor model, giving a false sense of security. For this reason, we use the stepwise regression only to validate our conclusions.

Despite the interesting properties of model (1), this specification does not take into account the fact that data are censored. At the same time, standard censored regression models are described by nonlinear functions and therefore the usual maximum likelihood estimator for fixed effects leads to biased and inconsistent results. ${ }^{4}$ Moreover, as stated by Honoré (1992): 'The problems with estimating limited dependent variable models with fixed effects from panel data are most acute when the time dimension of the panel is low'. To avoid these problems, Honoré proposes a semiparametric, fixed effects estimator for truncated and censored regression models in panel data with just two or three periods. Therefore, following this approach, we use a trimmed least squares estimator, obtaining parameters that are both asymptotically consistent and easy to calculate.

When data are censored, the observed $E X_{i t}$ is defined by the following measurement equation:

$$
E X_{i t}=\left\{\begin{array}{c}
E X_{i t}^{*} \text { if } E X_{i t}>0 \\
0 \text { if } E X_{i t}=0
\end{array}\right.
$$

where $E X_{i t}^{*}$ is a latent variable that is observed for export shares greater than 0 and censored otherwise.

The estimated model is

$$
E X_{i t}^{*}=\alpha+\beta I P_{i t}+\gamma d_{i} I P_{i t}+\delta^{\prime} X_{i t}+\mu_{i}+\delta t+\varepsilon_{i t},
$$

where $\delta t$ captures the existence of a time-trend emerging from (1). ${ }^{5}$ Note that, with respect to the standard Tobit model, we do not need to assume either a parametric form for the disturbances nor homoskedasticity across observations. Inference is based on the method of kernels. This method allows us to obtain consistent estimates of the variances of coefficients (see Honoré, 1992: 546).

After having studied the role of heterogeneity and censoring on our baseline model, we must verify that the nature of family firms affects the relationship between informal payments and international orientation. That is, we must check that our main explanatory variables are not proxying other channels affecting the export share. To do this, we estimate two confounding models:

i) we replace $I P$ with a variable measuring those informal payments not related to international orientation. This variable is the percentage of total sales that an establishment pays to secure or attempt to secure public contracts $(I P C)$. If $I P$ refers to bribes paid to get things done, $I P C$ is related to

\footnotetext{
${ }^{4}$ The terminology censored regression model could be misleading in this case. Following Wooldridge (2002), we should refer to our model as a corner solution model. In a corner solution model, the issue is not data observability, but measures such as $E\left(E X_{i t}\right)$ and the marginal effects of the explanatory variables on the outcome variable. In this setting, ordinary least squares (OLS) estimation leads to estimates that are biased and inconsistent, whereas Tobit estimates are consistent and asymptotically normal (Amemiya, 1973).

${ }^{5}$ We use a time-trend variable because Honoré's method does not allow for the inclusion of dummy variables.
} 
payments devoted to eliminate domestic competition. For this reason, family firms that pay to secure public contracts should be less inclined to face international competition;

ii) we replace the dummy variable for family firms with a dummy variable for individual firms. In this way, we aim at excluding that the former is proxying some common traits with individual firms (see Section 1).

We expect these models to be less appropriate than our initial specification.

When we estimate the relationship between informal payments and the decision to export, simultaneity problems can easily arise. On the one hand, by facing high informal costs, firms may decide to avoid part of these costs by just looking at alternative markets. On the other hand, the decision to export may cause additional informal costs due to the acquisition of licenses, taxes and shipping procedures. Therefore, we use a control function (CF) approach to test whether our results are affected by an endogeneity bias. Following Wooldridge (2002: 612), we use a control function method to estimate a nonlinear panel data model with unobserved heterogeneity and endogenous explanatory variables. Consider the following model:

$$
E\left(E X_{i t} \mid I P_{i t}, X_{i t}, \mu_{i}, \varepsilon_{i t}\right)=f\left(I P_{i t}, X_{i t}, \mu_{i}, \varepsilon_{i t}\right)
$$

where $f$ is a general nonlinear function, $X_{i t}$ is a matrix of strictly exogenous variables, whereas $I P_{i t}$ is allowed to be correlated with $\varepsilon_{i t}$. We then estimate the following linear reduced form:

$$
I P_{i t}=a+b X_{i t}+c Z_{i t}+u_{i t}
$$

where $Z_{i t}$ is a matrix of excluded regressors. We compute $\widehat{u}_{i t}$ from (5) and insert it into (4). That is, we estimate the following second-stage equation:

$$
E\left(E X_{i t} \mid I P_{i t}, X_{i t}, \mu_{i}, \varepsilon_{i t}\right)=f\left(I P_{i t}, X_{i t}, \mu_{i}, \widehat{u}_{i t}, \varepsilon_{i t}\right) .
$$

In other words, the control function method is based on a simple two-step procedure. First, we estimate a reduced form (pooled across $t$ ) for the percentage of informal payments, obtaining the residuals, $\widehat{u}_{i t}$ for all pairs $(i, t)$. Second, we estimate a Tobit model augmented by the vector of residuals $\widehat{u}_{i t}$. To account for first-stage estimation, inference is based on a bootstrap method.

The intuition behind the CF method is the following: if a covariate is affected by the outcome variable, regressing this covariate on a set of exogenous regressors would lead to an error term correlated with the initial outcome, therefore, including this error term in the second-stage equation will lead to less biased estimates. For linear models, the control function approach mimics two-stage least squares, while for nonlinear models it offers some important advantages (see Cameron \& Trivedi, 2013).

\section{Results}

Our main task was to test whether the impact of informal costs on the export share changes between family and non-family firms. Table 2 presents the 
estimates for the export share. ${ }^{6}$

Column 1 reports the estimated coefficients of equation (1). By including firms fixed effects in a simple linear regression, we can see that the explanatory power of our model is extremely high $\left(R^{2}=79 \%\right)$. The Rho-statistic shows that $83 \%$ of the variance is explained by unobserved heterogeneity. Furthermore, only the interaction term $d_{i} I P_{i t}$ has a positive and statistically significant coefficient, while for non-family firms the impact of informal costs on the export share is negligible. The existence of a positive correlation between informal costs and the export share for family firms implies that a higher export share is associated with higher informal costs. Nonetheless, before drawing any conclusion, several robustness checks are needed.

For this reason, in Column 2, we try to mitigate multicollinearity problems. Column 2 contains the coefficients of a linear stepwise regression with fixed effects. We first use a within transformation and then we run a stepwise regression. ${ }^{7}$ From this column, we can conclude that multicollinearity does not invalidate our main conclusion. That is, informal costs affect the export share only if we consider family firms. Moreover, once we control for multicollinearity problems, the coefficients of some explanatory variables become statistically significant. In particular, according to export-oriented firms, the lack of credit is one of the major problems for their activity. At the same time, the export share increases with the number of non-production workers such as managers, administrators and commercial employees. Similarly, the export share is negatively associated with R\&D activity driven by domestic competitors or customers. Besides, the export share is positively related to a measure of business control such as the share held by the largest owner(s).

Finally, Column 3 reports our Tobit fixed effects estimates. These estimates take into account the censored nature of our dependent variable, and they are specifically designed for panels in which the number of periods is smaller than three. Again, the coefficient of the interaction term is positive and statistically significant at $1 \%$. Here, as in Column 2, internationally-oriented firms are more sensitive to credit availability. We also confirm the previous findings about the number of non-production workers and the R\&D activity coming from customers' pressure. Although, Tobit coefficients, especially these ones, are not so easy to interpret, their sign confirms what we previously found with a simple linear regression: only family firms show a negative correlation between the export share and the fraction of informal payments.

\footnotetext{
${ }^{6}$ We reported only those variables for which the estimates are statistically significant in at least one model. However, tables with all coefficients are available upon request.

${ }^{7}$ Note that, during this process, the error variance must be adjusted. The adjustment is $q=1+\frac{n-1}{N-K-n}$, where $N$ is the total sample, $K$ is the number of regressors, and $n$ is the cross-sectional size.
} 
Table 2: Export Share and $I P$

\begin{tabular}{lccc}
\hline \hline & Linear FE & SW FE & Tobit FE \\
\hline Constant & 40.958 & 12.09 & \\
& $(124.849)$ & $(3.607)^{* * *}$ & \\
$I P_{i t}$ & -0.212 & & -0.264 \\
& $(0.299)$ & & $(0.528)$ \\
$d_{i} I P_{i t}$ & 6.508 & 7.089 & 9.047 \\
& $(2.956)^{* *}$ & $(1.867)^{* * *}$ & $(1.965)^{* * *}$ \\
R\&D: dom. comp. & -1.163 & -1.438 & -3.756 \\
& $(0.966)$ & $(0.659)^{* *}$ & $(3.079)$ \\
R\&D: cust. & -1.474 & -1.819 & -10.723 \\
& $(0.861)^{*}$ & $(0.693)^{* * *}$ & $(4.845)^{* *}$ \\
Ownership & 0.081 & 0.07 & 0.36 \\
& $(0.083)$ & $(0.033)^{* *}$ & $(0.209)^{*}$ \\
Credit constraints & 0.761 & 1.095 & 1.66 \\
& $(1.049)$ & $(0.534)^{* *}$ & $(2.602)$ \\
Non-prod. workers & 0.047 & 0.044 & 0.104 \\
& $(0.028)$ & $(0.011)^{* * *}$ & $(0.046)^{* *}$ \\
Additional controls & Yes & No & Yes \\
\hline Observations & 953 & 953 & 953 \\
R-squared & 0.79 & & \\
Rho & 0.83 & & \\
\hline Standard errors in parentheses. & & \\
Significant at : ${ }^{*} 10 \% ; * *$ & $5 \% ; * * *$ & $1 \%$. & \\
\hline \hline
\end{tabular}

Following the structure of Table 2, Table 3 reports the impacts of our control variables on firms' export share. As before, Column 1 shows that the inclusion of fixed effects in a linear model noticeably improves the fit. Also, our model explains more than eighty percent of variability, with almost ninety percent of this variation explained by individual fixed effects. Informal payments to secure public contracts are negatively related to the export share, and the magnitude of this effect increases when we consider the interaction term with the family business dummy variable. This means that firms paying to secure domestic, public contracts are less interested in exporting their products. One can argue that public contracts mainly refer to non-tradable good sectors. However, this effect is particularly severe for family firms even after having controlled for individual characteristics.

Column 2 of Table 3 supports the idea that multicollinearity might cover some significant relationships between our explanatory variables and the export share. When we use a stepwise regression method to select a smaller set of covariates, the role of some explanatory variables in explaining the export share arises. As before, there is a positive correlation between the number of white collar workers and the export share. Now, investments in formal training and firm's exports are positively associated, while R\&D activity due to customers' pressure is still inversely related to export. Finally, the percentage of firm owned by the largest owner(s) and the credit availability exhibit a weak link with our dependent variable.

Tobit estimates with fixed effects are reported in Column 3. Again, family firms paying to secure public contracts export less than non-family firms paying the same informal costs. This suggests a sort of selection mechanism according 
to which the existence of corruption costs increases the probability of family firms to trade mainly in domestic markets. By looking at Table 2, we can see that the opposite mechanism holds when corruption costs are intended to get things done. These two effects suggest a larger sensitivity of family firms' exports to corruption opportunities (treats). In other words, anti-corruption policies will especially affect family firms' exports. However, this conclusion must be supported by a robustness analysis.

Table 3: Export Share and IPC

\begin{tabular}{lccc}
\hline \hline & Linear FE & SW FE & Tobit FE \\
\hline$I P C_{i t}$ & -0.375 & -0.336 & -1.689 \\
& $(0.198)^{*}$ & $(0.128)^{* * *}$ & $(0.862)^{* *}$ \\
$d_{i} I P C_{i t}$ & -2.387 & -2.426 & -3.182 \\
& $(1.246)^{*}$ & $(0.66)^{* * *}$ & $(1.294)^{* *}$ \\
R\&D: cust. & -1.445 & -1.551 & -8.989 \\
& $(0.859)$ & $(0.582)^{* * *}$ & $(3.459)^{* * *}$ \\
Ownership & 0.075 & 0.067 & 0.303 \\
& $(0.066)$ & $(0.031)^{* *}$ & $(0.193)$ \\
Credit Access & 0.822 & 0.829 & 2.603 \\
& $(0.916)$ & $(0.472)^{*}$ & $(2.877)$ \\
Non-prod. workers & 0.054 & 0.051 & 0.137 \\
& $(0.026)^{*}$ & $(0.01)^{* * *}$ & $(0.060)^{* *}$ \\
Training & 2.305 & 2.573 & 14.979 \\
& $(1.445)$ & $(1.213)^{* *}$ & $(7.319)^{* *}$ \\
Additional controls & Yes & No & Yes \\
\hline Observations & 917 & 917 & 917 \\
R-squared & 0.84 & & \\
Rho & 0.87 & & \\
\hline Standard errors in parentheses. & & \\
Significant at $:{ }^{*} 10 \% ;$ & ${ }^{* *} 5 \% ; * *$ & $1 \%$. & \\
\hline \hline
\end{tabular}

Table 4 provides two important robustness checks. In the first two columns, we conducted a counterfactual exercise for both $I P$ and IPC. In particular, we tested whether our results truly refer to the family dimension of firms. In Columns 1 and 2, we replaced the dummy for family firms with a dummy for individual firms. A family business is an economic organization in which the decision-making process is influenced by multiple generations of a family. Vice versa, owner-manager entrepreneurial firms are not family businesses because they lack the multigenerational dimension and family influence. Therefore, even if individual and family businesses share some common traits, this feature strongly affects the dynamics and relationships of family businesses. We can conclude that our interaction term, $d_{i} I P_{i t}$, is not proxying other dimensions, but it identifies the effect of $I P$ on the export share passing through family business characteristics. The same conclusion holds for $I P C$, where the interaction term shows that individual firms that pay more to secure public contracts also export more.

Finally, Columns 3 and 4 of Table 4 provide the results of our control function method. This method is devoted to detecting and correcting endogeneity bias. The coefficients for the first stage error term show that endogeneity is an issue only for $I P C$. When we control for the first stage error term, the interaction 
term $d_{i} I P C_{i t}$ becomes statistically insignificant. This means that the negative coefficient reported in Table 3 might be a signal of reverse causality: family firms that do not export, perhaps because they are not so competitive, tend to pay a bribe to secure public contracts. In contrast, once we control for endogeneity, a positive relationship between $I P C$ and the export share emerges. This is consistent with the idea that non-family firms decide to export in order to avoid informal costs related to puclic contracts. However, the reverse channel going from the export share to informal payments masks this evidence leading to the negative coefficient of IPC found in Table 3.

On the contrary, the coefficient of $d_{i} I P_{i t}$ remains negative and statistically significant even when we include the first stage error term obtained from the CF method. The magnitude of this coefficient is comparable with the coefficient reported in the last column of Table 2. The economic intuition is the following: family firms that are internationally-oriented pay informal costs to facilitate their operations on the international market. From points of view of policymakers and regulators, the fight against and prevention of these informal costs will not benefit family firms as long as governments will not remove the inefficiencies that firms intend to overcome with these payments.

Table 4: Robustness checks for export share (Tobit FE)

\begin{tabular}{lrrrr}
\hline \hline & Indiv. firms & Indiv. firms & \multicolumn{1}{c}{ CF } & \multicolumn{1}{c}{ CF } \\
\hline \multirow{2}{*}{$I P_{i t}$ (or $\left.I P C_{i t}\right)$} & $I P$ & $I P C$ & $I P$ & $I P C$ \\
$d_{i} I P_{i t}$ (or $\left.d_{i} I P C_{i t}\right)$ & -0.228 & -3.972 & -11.888 & 9.689 \\
& $(0.908)$ & $(0.733)^{* * *}$ & $(17.018)$ & $(5.182)^{*}$ \\
CF & 0.397 & 3.717 & 9.946 & -0.767 \\
& $(1.088)$ & $(0.780)^{* * *}$ & $(2.395)^{* * *}$ & $(2.498)$ \\
R\&D: custom. & & 11.321 & -11.653 \\
& -9.776 & -9.034 & -12.35 & -9.872 \\
Ownership & $(4.530)^{* *}$ & $(3.495)^{* * *}$ & $(5.190)^{* *}$ & $(3.298)^{* * *}$ \\
& 0.357 & 0.256 & 0.35 & 0.271 \\
Non-prod. workers & $(0.233)$ & $(0.134)^{*}$ & $(0.266)$ & $(0.181)$ \\
& 0.104 & 0.137 & 0.1 & 0.243 \\
Training & $(0.045)^{* *}$ & $(0.058)^{* *}$ & $(0.074)$ & $(0.116)^{* *}$ \\
& 8.572 & 14.724 & 11.697 & 6.216 \\
Time & $(6.723)$ & $(5.920)^{* *}$ & $(8.405)$ & $(5.734)$ \\
& 1.143 & 0.038 & 0.585 & -1.818 \\
Additional controls & $(1.257)$ & $(1.220)$ & $(1.816)$ & $(0.873)^{* *}$ \\
\hline Observations & Yes & Yes & Yes & Yes \\
\hline Standard errors in parentheses. Significant at $*^{*} 10 \% ; * *$ & $5 \% ; * * * 1 \%$. \\
\hline \hline
\end{tabular}

\section{Concluding remarks}

In this paper, we investigated the relationship between corruption costs and family firms' market orientation. By using firm-level data conceived to build comparative measures across Eastern European countries, we carried out a panel data analysis designed to control for unobservable heterogeneity. In particular, after having estimated the usual linear models (with and without model selec- 
tion techniques), we employed a robust semiparametric estimator to control for censoring and heterogeneity problems.

Despite some common and important limitations such as the fact that the analysis relies on survey data instead of observational data and we cannot distinguish between domestic and foreign corruption, this paper sheds some light on the role played by the informal economy on family firms.

Our main result is that, in terms of international orientation, corruption costs affect family firms more than non-family ones. In other words, family businesses are more prone to use informal channels to reach their goals than non-family businesses. However, it is important to distinguish the grounds for informal costs. If informal payments are devoted to facilitate business' operations, these costs tend to increase family firms' exports. In contrast, if informal payments are devoted to securing public contracts, these additional costs tend to be inversely related to exports. More specifically, family firms that decided to produce mainly for domestic markets are also more inclined to bear these costs. To conclude, a government can increase family firms' international competitiveness removing those market and institutional inefficiencies that hamper business operations. This intervention will lower family firms' costs and boost economic growth and development. 


\section{References}

[1] Aguilera, R., \& Vadera, A. (2008). The dark side of authority: Antecedents, mechanisms, and outcomes of organizational corruption. Journal of Business Ethics, 77(4), 431-449.

[2] Allio, M. (2004). Family businesses: Their virtues, vices and strategic path. Strategy and Leadership, 32, 24-34.

[3] Alon, A. \& Hageman, A.M. (2013). The Impact of Corruption on Firm Tax Compliance in Transition Economies: Whom Do You Trust? Journal of Business Ethics, 116, 479-494.

[4] Amemiya, T. (1973). Regression analysis when the dependent variable is truncated normal. Econometrica, 41, 997-1016.

[5] Ampratwum, E. F. (2008). The fight against corruption and its implications for development in developing and transition economies. Journal of Money Laundering Control, 11(1), 76-87.

[6] Aronoff, C. E. \& Ward, J. L. (1995). Family- Owned Businesses: A Thing of the Past or a Model for the Future?. Family Business Review, 8(2), 121-130.

[7] Astrachan, J. H. (2010). Strategy in family business: Toward a multidimensional research agenda. Journal of Family Business Strategy, 1(1), 6-14.

[8] Beckhard R. \& Dyer W. (1983). Managing continuity in family owned business. Organizational Dynamics, 12(1), 5-12.

[9] Bertrand, M. \& Schoar, A. (2006). The role of family in Family Firms. The Journal of Economic Perspectives, 20(2), 73-96.

[10] Burkart, M., Panunzi, F. \& Shleifer, A. (2003). Family Firms. Journal of Finance, 58(5), 2167-202.

[11] Cameron, C. \& Trivedi, P.K. Regression Analysis of Count Data 2nd edition. Cambridge University Press, 2013.

[12] Campos, J. E., Lien, D., \& Pradhan, S. (1999). The impact of corruption on investment: Predictability matters. World Development, 27(6), 1059-1067.

[13] Caselli, F. \& Gennaioli, N. (2003). Dynastic Management, NBER Working Paper No. 9442.

[14] Casson, M. (1999). The economics of the family firm. Scandinavian Economics History Review, 47, 10-23.

[15] Casson, M. (2000). The family firm: An analysis of the dynastic motive. In M. Casson, Enterprise and leadership: Studies on firms, markets and networks. Edward Elgar, United Kingdom.

[16] Chandler, A. D. (1990). Scale and scope: The dynamics of industrial capitalism. Cambridge, MA: Belknap Press. 
[17] Chen, Q., Hou,W., Li,W., Wilson, C. \& Wu, Z. (2014). Family Control, Regulatory Environment, and the Growth of Entrepreneurial Firms: International Evidence. Corporate Governance: An International Review, 22(2), 132-144.

[18] Chrisman J.J, Chua J.H., \& Litz, R. A. (2004). Comparing agency costs of family and non family firms: conceptual issues and exploratory evidence. Entrepreneurship Theory and Practice, 28(4), 335-354.

[19] Chrisman J.J., Chua J.H., \& Sharma, P. (2005). Trends and Directions in the Development of a Strategic management Theory of the Family Firm. Entrepreneurship Theory and Practice, 5, 555-576.

[20] Chrisman, J. \& Patel, P. (2012). Variations in R\&D investments of family and non-family firms: Behavioral agency and myopic loss aversion perspectives. Academy of Management Journal, 55, 976-997.

[21] Chua, J. H., Chrisman, J. J. \& Sharma, P. (1999). Defining the Family Business by Behavior. Entrepreneurship: Theory and Practice, 23(4), 1939.

[22] Corbetta, G., \& Montemerlo, D. (1999). Ownership, governance and management issues in small and medium-size family businesses: a comparison of Italy and the United States. Family Business Review, 12(4), 361-374.

[23] Davis, P. (1983). Realizing the potential of the family business. Organizational dynamics, 12(1), 47-56.

[24] Davis, J. A., \& Tagiuri, R. (1989). The Influence of Life Stage on FatherSon Work Relationships in Family Companies. Family Business Review, 2, 47-74.

[25] Davis, J. H., Schoorman, F. D., \& Donaldson, L. (1997). Toward a stewardship theory of management. Academy of Management Review, 22, 20-47.

[26] de la Croix, D., \& Delavallade, C. (2009). Growth, public investment and corruption with failing institutions. Economics of Governance, 10(3), 187219.

[27] Donnelley., R. (1964). The family business. Harvard Business Review, 42, 93-105.

[28] Dunning, J.H. (1988). The eclectic paradigm of international production: a restatement and some possible extensions. Journal of International Studies, $19(1), 1-31$.

[29] Evans, B. R. (1999). The cost of corruption. A discussion paper on corruption, development and the poor, Teddingtion, Middlesex: Tearfund.

[30] Fernandez, Z., \& Nieto, M. J. (2006). Impact of ownership on the international involvement of SMEs. Journal of International Business Studies, 37, 340-351. 
[31] Fisman, R. \& Svensson, J. (2007). Are corruption and taxation really harmful to growth? Firm level evidence. Journal of Development Economics, $83(1), 63-75$

[32] Gallo, M.A., \& Pont, C.G., (1996). Important factors in family business internationalization. Family Business Review, 9(1), 45-60.

[33] Gómez-Mejía, L. R., Haynes, K. T., Núñez-Nickel, M., Jacobson, J. L. K., \& Moyano-Fuentes, J. (2007). Socioemotional wealth and business risks in family-controlled firms: Evidence from Spanish olive oil mills. Administrative Science Quarterly, 52, pp.106-137.

[34] Gómez-Mejía, L. R., Makri, M., \& Larraza-Kintana, M. (2010). Diversification decisions in family controlled firms. Journal of Management Studies, 47: $223-252$.

[35] Gómez-Mejía, L. R., Cruz, C., Berrone, P., \& Castro, J. (2011). The bind that ties: Socioemotional wealth preservation in family firms. The Academy of Management Annals, 5, 653-707.

[36] Grassby, R. (2000). Kinship and capitalism. Cambridge, MA: Cambridge University Press.

[37] Habbershon T.G., Williams M.L, \& Macmillan I. (2003). An unified systems prospective of family firm performance, Journal of Business Venturing, 18(4), 451-465.

[38] Habib, M., \& Zurawicki, L. (2002). Corruption and foreign direct investment. Journal of International Business Studies, 33(2), 291-307.

[39] Hall, R. E., \& Jones, C. I. (1999). Why do some countries produce so much more output per worker than others? The Quarterly Journal of Economics, 114(1), 83-116.

[40] Handler, W.C. (1989). Methodological issue and consideration in studying family business. Family business review, 3(2), 257-276.

[41] Hausman, J. A. 1978. Specification tests in econometrics. Econometrica 46: $1251-1271$

[42] Hellman, J.S., Jones, G., Kaufman, D., \& Shankerman, M. (2000). Measuring governance, corruption and state capture: How firms and bureaucrats shape the business environment in transition economies. World Bank Policy Research Working Papers 2312. Washington, DC: The World Bank.

[43] Honoré B.E. (1992). Trimmed Lad and Least Squares Estimation of Truncated and Censored Regression Models with Fixed Effects. Econometrica, 60(3), 533-565.

[44] International Family Enterprise Research Academy (2003). Family businesses dominate, family business review, 4.

[45] Ionov, A. 2014. Can family businesses take hold in Russia? EY Family Business Center of Excellence, Posted on June 23, 2014, accessible through http://familybusinessblog.ey.com/2014/06/23/can-familybusinesses-take-hold-in-russia/. 
[46] Jehn, K. A. (1997). A quantitative analysis of conflict types and dimensions in organizational groups. Administrative Science Quarterly, 42, 530-558.

[47] Kepner, E. (1991) The family and the firm: a coevolutionary prospective. Family Business Review, 4(4), 445-461.

[48] KMU Forschung Austria. (2008). Overview of family business relevant issues. Vienna.

[49] Kontinen, T. \& Ojala, A. (2010). The internationalization of family business: a review of extant research. Journal of Family Business Strategy, 1, $97-107$.

[50] Landes, D. (1949). French entrepreneurship and industrial growth in the nineteenth century. Journal of Economic History, 9, 45-61.

[51] Lansberg I.S. (1983). Managing human resources in family firm: problems of institutionally overlap, Organizational dynamics, 12 (1), 39-46.

[52] Lansberg, I. (1999). Succeeding Generations: Realizing the Dream of Families in Business. Harvard Business School Press, Boston, MA.

[53] Lapalombara, J. (1994). Structural and institutional aspects of corruption. Social Research, 61(2), 325-350.

[54] La Porta, R., Lopez-de-Silanes, F., Shleifer, A., \& Vishny, R. (1999). Corporate Ownership Around the World. Journal of Finance, 54(2), 471-517.

[55] Lattanzi, N., \& Lazzini, A. (2005). Family Business: a comparative study between Italian and Us family firms. A special view on cognitive process dynamic in the family business context. Working papers presented at "Workshop on Family Firm Management Research" Jonkoping, Sweden, 9-11.

[56] Levinson, H. (1971). Conflicts that plague family businesses. Harvard Business Review, 49, 90-98.

[57] Litz, R.A. (1995). The family business: Toward definitional clarity. Family Business Review 8(2), 71-81.

[58] Lu, J.W., \& Beamish, P.W. (2001). The internationalization and performance of SMEs. Strategic Management Journal, 22 (6-7), 565-586.

[59] Mauro, P. (1995). Corruption and growth. The Quarterly Journal of Economics, 110(3), 681-712.

[60] McConaughy, D., Matthews, C., \& Fialko, A. (2001). Founding family controlled firms: Performance, risk, and value. Journal of Small Business Management, 39, 31-49.

[61] Miller, D., \& Le Breton-Miller, I. (2005). Managing for the long run: Lessons in competitive advantage from great family businesses. Boston, MA: Harvard Business School Press.

[62] Miller, D., Le Breton-Miller, I., \& Scholnick, B. (2008). Stewardship vs. stagnation: An empirical comparison of small family and non-family businesses. Journal of Management Studies, 45, 51-78. 
[63] Neubauer, F., \& Lank, A. G. (1998). The Family Business: Its Governance for Sustainability. New York: Routledge.

[64] Olney, W. (2014). Impact of Corruption on Firm Level Export Decisions. Working papers downloadable at: http://web.williams.edu/Economics/wp/OlneyCorruptionandExportingJuly2013.pdf

[65] Parker, B. (1998). Globalization and Business Practice: Managing Across Boundaries. Sage Publications, London.

[66] Poza, E. J., Alfred, T., \& Maheshwari, A. (1997). Stakeholder perceptions of culture and management practices in family and family firms. Family Business Review, 10, 135- 155.

[67] Prencipe, A., Bar-Yosef, S. \& Dekker, H.C. (2014). Accounting Research in Family Firms: Theoretical and Empirical Challenges. European Accounting Review, DOI: 10.1080/09638180.2014.895621

[68] Radaev, V. (2004). How trust is established in economic relationships when institutions and individuals are not trustworthy. In J. Kornai, B. Rothstein, and S. Rose-Ackerman (Eds.), Creating social trust in post-socialist transition (91-111). Basingstoke, U.K.: Palgrave.

[69] Robertson, C. J., \& Watson, A. (2004). Corruption and change: The impact of foreign direct investment. Strategic Management Journal, 25(4), 385-396.

[70] Rose, R. (2000). Getting things done in an anti-modern society: Social capital networks in Russia. In P. Dasgupta and I. Serageldin (Eds.), Social capital: A multifaceted perspective (147-171). Washington, DC: The World Bank.

[71] Sanders, W.G., \& Carpenter, M.A. (1998). Internationalization and firm governance: The roles of CEO compensation, top team composition, and board structure. Academy of Management Journal 41, 158-178.

[72] Schulze, W. S., Lubatkin, M. H., \& Dino, R. N. (2003). Exploring the agency consequences of ownership dispersion among the directors of private family firms. Academy of Management Journal, 46, 179-194.

[73] Schwab, K. (2012).The Global Competitiveness Report 2011-2012. World Economic Forum.

[74] Schwab, K. (2013).The Global Competitiveness Report 2013-2014. World Economic Forum.

[75] Sciascia, S., Mazzola, P., Astrachan, J.H. \& Pieper, T.M. (2012). The role of family ownership in international entrepreneurship: exploring nonlinear effects. Small Business Economics, 38, 15-31.

[76] Shanker, M.C., \& Astrachan, J.H. (1996). Myths and realities: Family businesses' contribution to the US Economy - A framework for assessing family business statistics. Family Business Review, 9(2), 107-123. 
[77] Sharma, P., Chrisman, J.J., \& Chua, J.H. (1996). A Review and Annotated Bibliography of Family Business Studies. Kluwer Academic Publishers, Boston, MA.

[78] Shleifer, A., \& Vishny, R. (1993). Corruption. The Quarterly Journal of Economics, 108(3), 599-617.

[79] Stern, M.H. (1986). Inside the family held business, New York, Harcourt brace Jovanovich.

[80] Tanzi, V. (1998). Corruption Around the World Causes, Consequences, Scope, and Cures. IMF Staff Papers, 45(4).

[81] Tonoyan, V., Strohmeyer, R., Habib, M. \& Perlitz, M. (2010). Corruption and Entrepreneurship: How Formal and Informal Institutions Shape Small Firm Behavior in Transition and Mature Market Economies. Entrepreneurship Theory and Practice, 34(5), 803-831.

[82] Zahra, S.A. (1996). Governance, ownership, and corporate entrepreneurship: the moderating impact of industry technological opportunities. Academy Management Journal, 39 (6), 1713-1735.

[83] Zahra, S., \& Garvis, S. (2000). International corporate entrepreneurship and company performance: the moderating effect of international environmental hostility. Journal of Business Venturing, 15 (5), 469-492.

[84] Zahra, S., \& George, G. (2002). International entrepreneurship: research contributions and future directions (chapter 12). In: Hitt, M., Ireland, D.R., Camp, M., Sexton, D.L. (Eds.), Strategic Entrepreneurship: Entrepreneurial Strategies for Wealth Creation. Blackwell, New York, NY, $255-288$.

[85] Zahra, S. (2003). International expansion of U.S. manufacturing family businesses: The effect of ownership and involvement. Journal of Business Venturing, 18, 495-512.

[86] Ward, J. L. (1997). Growing the family business: Special challenges and best practices. Family Business Review, 10(4), 323-337.

[87] Wooldridge, J.M. (2002). Econometric Analysis of Cross Section and Panel Data. MIT Press, Cambridge. 


\section{Technical Appendix (Not intended for publica- tion)}

This technical appendix reports Tables 2-4, including the coefficients of non significant variables.

Table 2: Export share and $I P$

\begin{tabular}{|c|c|c|c|}
\hline & Linear FE & SW FE & Tobit FE \\
\hline$I P_{i t}$ & $\begin{array}{l}-0.212 \\
(0.299)\end{array}$ & & $\begin{array}{l}-0.264 \\
(0.528)\end{array}$ \\
\hline$d_{i} I P_{i t}$ & $\begin{array}{c}6.508 \\
(2.956)^{* *}\end{array}$ & $\begin{array}{c}7.089 \\
(1.867)^{* * *}\end{array}$ & $\begin{array}{c}9.047 \\
(1.965)^{* * *}\end{array}$ \\
\hline Sales & $\begin{array}{c}4.99 \mathrm{e}-08 \\
(7.05 \mathrm{e}-08)\end{array}$ & & $\begin{array}{c}-9.85 \mathrm{e}-08 \\
(1.05 \mathrm{e}-07)\end{array}$ \\
\hline R\&D: domest. comp. & $\begin{array}{l}-1.163 \\
(0.966)\end{array}$ & $\begin{array}{c}-1.438 \\
(0.659)^{* *}\end{array}$ & $\begin{array}{c}-3.756 \\
(3.079)\end{array}$ \\
\hline R\&D: foreign comp. & $\begin{array}{l}-0.079 \\
(0.947)\end{array}$ & & $\begin{array}{c}1.914 \\
(2.587)\end{array}$ \\
\hline $\mathrm{R} \& \mathrm{D}$ : custom. & $\begin{array}{c}-1.474 \\
(0.861)^{*}\end{array}$ & $\begin{array}{c}-1.819 \\
(0.693)^{* * *}\end{array}$ & $\begin{array}{c}-10.723 \\
(4.845)^{* *}\end{array}$ \\
\hline Ownership & $\begin{array}{c}0.081 \\
(0.083)\end{array}$ & $\begin{array}{c}0.070 \\
(0.033)^{* *}\end{array}$ & $\begin{array}{c}0.36 \\
(0.209)^{*}\end{array}$ \\
\hline Establishment age & $\begin{array}{l}-0.018 \\
(0.062)\end{array}$ & & $\begin{array}{c}0.034 \\
(0.113)\end{array}$ \\
\hline Internat. certification & $\begin{array}{c}0.587 \\
(2.266)\end{array}$ & & $\begin{array}{c}4.323 \\
(6.760)\end{array}$ \\
\hline Credit constraints & $\begin{array}{c}0.761 \\
(1.049)\end{array}$ & $\begin{array}{c}1.095 \\
(0.534)^{* *}\end{array}$ & $\begin{array}{c}1.66 \\
(2.602)\end{array}$ \\
\hline Internal funds & $\begin{array}{c}0.018 \\
(0.023)\end{array}$ & & $\begin{array}{c}0.047 \\
(0.061)\end{array}$ \\
\hline Prod. workers & $\begin{array}{c}0.016 \\
(0.015)\end{array}$ & & $\begin{array}{c}0.014 \\
(0.018)\end{array}$ \\
\hline Non-prod. workers & $\begin{array}{c}0.047 \\
(0.028)\end{array}$ & $\begin{array}{c}0.045 \\
(0.011)^{* * *}\end{array}$ & $\begin{array}{c}0.104 \\
(0.046)^{* *}\end{array}$ \\
\hline Temporary workers & $\begin{array}{c}0.012 \\
(0.029)\end{array}$ & & $\begin{array}{l}-0.011 \\
(0.037)\end{array}$ \\
\hline Training & $\begin{array}{c}1.033 \\
(1.810)\end{array}$ & & $\begin{array}{c}8.775 \\
(6.673)\end{array}$ \\
\hline Year $=2005$ & $\begin{array}{c}-0.234 \\
(1.148)\end{array}$ & & \\
\hline Constant & $\begin{array}{c}40.958 \\
(124.849) \\
\end{array}$ & $\begin{array}{c}12.090 \\
(3.607)^{* * *} \\
\end{array}$ & \\
\hline Observations & 953 & & 953 \\
\hline \multicolumn{4}{|c|}{ Standard errors in parentheses. } \\
\hline
\end{tabular}


Table 3: Export share and IPC

\begin{tabular}{|c|c|c|c|}
\hline & Linear FE & SW FE & Tobit FE \\
\hline \multirow[t]{2}{*}{$I P C_{i t}$} & -0.375 & -0.336 & -1.689 \\
\hline & $(0.198)^{*}$ & $(0.128)^{* * *}$ & $(0.862)^{* *}$ \\
\hline \multirow[t]{2}{*}{$d_{i} I P C_{i t}$} & -2.387 & -2.426 & -3.182 \\
\hline & $(1.246)^{*}$ & $(0.66)^{* * *}$ & $(1.294)^{* *}$ \\
\hline \multirow[t]{2}{*}{ Sales } & $2.40 \mathrm{e}-08$ & & $-1.12 \mathrm{e}-09$ \\
\hline & $(6.40 \mathrm{e}-08)$ & & $(8.99 \mathrm{e}-08)$ \\
\hline \multirow[t]{2}{*}{ R\&D: domest. comp. } & 0.052 & & 0.673 \\
\hline & $(1.128)$ & & $(3.028)$ \\
\hline \multirow[t]{2}{*}{ R\&D: foreign comp. } & -0.586 & & -0.579 \\
\hline & $(0.790)$ & & $(2.555)$ \\
\hline \multirow[t]{2}{*}{ R\&D: custom. } & -1.445 & -1.551 & -8.989 \\
\hline & $(0.859)$ & $(0.582)^{* * *}$ & $(3.459)^{* * *}$ \\
\hline \multirow[t]{2}{*}{ Ownership } & 0.075 & 0.067 & 0.303 \\
\hline & $(0.066)$ & $(0.031)^{* *}$ & $(0.193)$ \\
\hline \multirow[t]{2}{*}{ Establishment age } & 0.006 & & 0.17 \\
\hline & $(0.067)$ & & $(0.119)$ \\
\hline \multirow[t]{2}{*}{ Internat. certification } & 2.126 & & 10.624 \\
\hline & $(2.567)$ & & $(8.770)$ \\
\hline \multirow[t]{2}{*}{ Credit constraints } & 0.822 & 0.829 & 2.603 \\
\hline & $(0.916)$ & $(0.472)^{*}$ & $(2.877)$ \\
\hline \multirow[t]{2}{*}{ Internal funds } & -0.014 & & -0.002 \\
\hline & $(0.018)$ & & $(0.052)$ \\
\hline \multirow[t]{2}{*}{ Prod. workers } & 0.008 & & -0.012 \\
\hline & $(0.022)$ & & $(0.036)$ \\
\hline \multirow[t]{2}{*}{ Non-prod. workers } & 0.054 & 0.051 & 0.137 \\
\hline & $(0.026)^{*}$ & $(0.01)^{* * *}$ & $(0.060)^{* *}$ \\
\hline \multirow[t]{2}{*}{ Temporary workers } & 0.01 & & -0.013 \\
\hline & $(0.037)$ & & $(0.040)$ \\
\hline \multirow[t]{2}{*}{ Training } & 2.305 & 2.573 & 14.979 \\
\hline & $(1.445)$ & $(1.213)^{* *}$ & $(7.319)^{* *}$ \\
\hline \multirow[t]{2}{*}{ Year $=2005$} & -1.017 & & \\
\hline & $(0.819)$ & & \\
\hline \multirow[t]{2}{*}{ Constant } & -8.725 & & \\
\hline & $(136.289)$ & & \\
\hline Observations & 917 & & 917 \\
\hline \multicolumn{4}{|c|}{ Standard errors in parentheses. } \\
\hline \multicolumn{4}{|c|}{ Significant at : ${ }^{*} 10 \% ;{ }^{* *} 5 \% ; * * * 1 \%$. } \\
\hline
\end{tabular}


Table 4: Robustness checks for export share (Tobit FE)

\begin{tabular}{|c|c|c|c|c|}
\hline & Indiv. firms & Indiv. firms & $\mathrm{CF}$ & $\overline{\mathrm{CF}}$ \\
\hline & $I P$ & $I P C$ & $I P$ & $I P C$ \\
\hline \multirow[t]{2}{*}{$I P_{i t}\left(\right.$ or $\left.I P C_{i t}\right)$} & -0.228 & -3.972 & -11.888 & 9.689 \\
\hline & $(0.908)$ & $(0.733)^{* * *}$ & $(17.018)$ & $(5.182)^{*}$ \\
\hline \multirow[t]{2}{*}{$d_{i} I P_{i t}\left(\right.$ or $\left.d_{i} I P C_{i t}\right)$} & 0.397 & 3.717 & 9.946 & -0.767 \\
\hline & $(1.088)$ & $(0.780)^{* * *}$ & $(2.395)^{* * *}$ & $(2.498)$ \\
\hline \multirow[t]{2}{*}{$\mathrm{CF}$} & & & 11.321 & -11.653 \\
\hline & & & $(17.178)$ & $(5.146)^{* *}$ \\
\hline \multirow[t]{2}{*}{ Sales } & $-8.57 \mathrm{e}-08$ & $-3.70 \mathrm{e}-08$ & $-2.20 \mathrm{e}-07$ & $-1.99 \mathrm{e}-07$ \\
\hline & $(1.05 \mathrm{e}-07)$ & $(8.17 \mathrm{e}-08)$ & $(1.44 \mathrm{e}-07)$ & $(1.46 \mathrm{e}-07)$ \\
\hline \multirow[t]{2}{*}{ R\&D: dom. comp. } & -3.86 & 0.377 & -4.039 & 2.972 \\
\hline & $(2.943)$ & $(2.399)$ & $(3.309)$ & $(2.265)$ \\
\hline \multirow[t]{2}{*}{ R\&D: foreign comp. } & 0.885 & -0.916 & 3.246 & -0.036 \\
\hline & $(2.730)$ & $(2.276)$ & $(4.432)$ & $(3.509)$ \\
\hline \multirow[t]{2}{*}{ R\&D: custom. } & -9.776 & -9.034 & -12.35 & -9.872 \\
\hline & $(4.530)^{* *}$ & $(3.495)^{* * *}$ & $(5.190)^{* *}$ & $(3.298)^{* * *}$ \\
\hline \multirow[t]{2}{*}{ Ownership } & 0.357 & 0.256 & 0.35 & 0.271 \\
\hline & $(0.233)$ & $(0.134)^{*}$ & $(0.266)$ & $(0.181)$ \\
\hline \multirow[t]{2}{*}{ Intern. certification } & 0.044 & 0.144 & 0.045 & 0.068 \\
\hline & $(0.106)$ & $(0.106)$ & $(0.231)$ & $(0.211)$ \\
\hline \multirow[t]{2}{*}{ Establishment age } & 4.681 & 7.189 & -0.889 & 2.732 \\
\hline & $(6.440)$ & $(7.599)$ & $(9.470)$ & $(6.970)$ \\
\hline \multirow[t]{2}{*}{ Credit constraints } & 1.834 & 1.935 & 6.214 & -2.376 \\
\hline & $(2.754)$ & $(2.312)$ & $(5.205)$ & $(2.872)$ \\
\hline \multirow[t]{2}{*}{ Internal funds } & 0.049 & 0.008 & 0.088 & -0.072 \\
\hline & $(0.062)$ & $(0.044)$ & $(0.115)$ & $(0.052)$ \\
\hline \multirow[t]{2}{*}{ Prod. workers } & 0.014 & -0.029 & -0.012 & 0.064 \\
\hline & $(0.018)$ & $(0.043)$ & $(0.037)$ & $(0.090)$ \\
\hline \multirow[t]{2}{*}{ Non-prod. workers } & 0.104 & 0.137 & 0.1 & 0.243 \\
\hline & $(0.045)^{* *}$ & $(0.058) * *$ & $(0.074)$ & $(0.116)^{* *}$ \\
\hline \multirow[t]{2}{*}{ Temporary workers } & -0.01 & -0.016 & 0.231 & 0.124 \\
\hline & $(0.037)$ & $(0.039)$ & $(0.311)$ & $(0.370)$ \\
\hline \multirow[t]{2}{*}{ Training } & 8.572 & 14.724 & 11.697 & 6.216 \\
\hline & $(6.723)$ & $(5.920)^{* *}$ & $(8.405)$ & $(5.734)$ \\
\hline \multirow[t]{2}{*}{ Time } & 1.143 & 0.038 & 0.585 & -1.818 \\
\hline & $(1.257)$ & $(1.220)$ & $(1.816)$ & $(0.873)^{* *}$ \\
\hline Observations & 953 & 917 & 879 & 841 \\
\hline \multicolumn{5}{|c|}{ Standard errors in parentheses. } \\
\hline \multicolumn{5}{|c|}{ Significant at: ${ }^{*} 10 \% ;{ }^{* *} 5 \% ;{ }^{* * *} 1 \%$. } \\
\hline
\end{tabular}

